\title{
Distribution, Mineralogy, Petrography, Provenance and Significance of Permian Ash-Carrying Deposits in the Paraná Basin
}

\author{
José Moacyr Vianna Coutinho' (mlcout@osite.com.br) and Jorge Hachiro² \\ 'Departamento de Mineralogia e Geotectônica - Instituto de Geociências - USP \\ R. do Lago 562, CEP 05508-080, São Paulo, SP, BRA \\ ${ }^{2}$ Departamento de Geologia Sedimentar e Ambiental - Instituto de Geociências - USP, São Paulo, SP, BRA
}

Received 29 April 2004; accepted 01 December 2004

Keywords: ash deposits, mineralogy, provenance, Permian Gondwana, Paraná Basin.

\begin{abstract}
The study of thin sections taken from drill core samples and outcrops in southern Brazil has demonstrated the occurrence of repeated ash fall episodes during the Permian period between 280 and 245 Ma. Scattered or concentrated altered volcanic glass shards were detected in strata of Permian sedimentary rocks of the Rio Bonito and Tatui Formations. The shardcarrying sediment is usually a silty or cherty mudstone with variable amounts of calcrete calcite. Burial and alteration of unstable glass debris led to the development of analcite and less commonly, calcite, silica minerals, zeolites or montmorillonite. Sources of explosive Permian volcanism, responsible for ample ash falls have been sought in South Africa, in the Andean Cordillera and along the Paraná Basin margin. A swarm of rhyolitic centers described in the Cordillera Frontal and in the Central Argentinian Provincia de La Pampa (Patagonia) is here proposed as the most adequate Permian source. In that area, volcanoes must have expelled ashes that traveled thousands of kilometers before settling in deltaic or shallow marine environments. Twenty-three occurrences of Permian shard-carrying sediments have been plotted in a Paraná Basin map. The number of ash-carrying sediments decreases northeastward. The authors envisage dense clouds originated in Patagonia traveling NE, depositing progressively smaller quantities of ashes but reaching Australia in pre-drift Gondwana. Shard carrying sediments must be distinguished from "tonstein", ash fall or ash flow tuffs, also recorded in the Permian Gondwana, which would indicate closer ash source area.
\end{abstract}

Palavras-chave: depósito de cinzas, mineralogia, origem, Gondwana permiano, Bacia do Paraná.

\section{RESUMO}

Seç̧ões delgadas de testemunhos de sondagem e afloramentos no sul do Brasil demonstraram a ocorrência de freqüentes quedas de cinzas vulcânicas durante o Permiano entre 280 e 245 Ma. Minúsculas $(c a .0,1 \mathrm{~mm}$ ) lascas de vidro vulcânico (glass shards) alterado, encontram-se dispersas ou concentradas nos sedimentos permianos das formações Rio Bonito e Tatuí, na Bacia do Paraná. O sedimento portador de glass shards é geralmente um lamito siltoso contendo em geral variável quantidade de calcita calcrete. Restos vítreos soterrados foram substituídos por analcita ou mais raramente calcita, sílica, zeólitas ou montmorilonita. Explosões vulcânicas são responsáveis por queda de cinzas em extensas áreas, e por isso, um possível vulcanismo permiano gerador foi procurado na África do Sul, na Cordilheira Andina e margens da Bacia do Paraná. Foi proposta como fonte mais adequada deste vulcanismo um enxame de centros riolíticos descritos na Cordilheira Frontal e na Província Argentina de La Pampa (Patagônia). Nesta área os vulcões devem ter expelido cinzas que caminharam milhares de quilômetros antes de se depositarem e se preservarem em ambientes deltaicos ou marinhos rasos. Vinte e três ocorrências conhecidas de sedimentos permianos contendo glass shards foram locados em mapa da Bacia do Paraná. Os relatos de ocorrência deste tipo de sedimento são gradualmente decrescentes para NE. Por esse motivo, os autores imaginam densas nuvens provindas da Patagônia e alcançando a Austrália, depositando quantidades cada vez menores de material à medida que se deslocavam. Sedimentos com shards devem ser diferenciados dos tonsteins, ash falls e ash flows que têm sido também registradas no Gondwana permiano e que seriam indicadoras de fontes mais próximas. 


\section{INTRODUCTION}

During a drilling campaign in the Paraná Basin (1981 1983), researchers of the Instituto de Pesquisas Tecnológicas de São Paulo, IPT, SA had the opportunity to examine hundreds of thin sections of sedimentary rock core samples. The purpose of the investigation was to reveal features of diagenesis and porosity that could help in the search for oil and gas. The attention of the senior author was incidentally called to the presence of microscopic "glass" shards in mudstone, siltstone and limestone samples from Permian formations. The unique shard shapes were incontrovertible but their glassy condition was disputable. X- ray examination proved that the isotropic low refringent matter of most shards was actually analcite, a replacement product of the original glass. In a number of samples optical microscopy indicated that the shards were partially or completely replaced by zeolites, microcrystalline quartz, calcite or even clay minerals. In any case, and to simplify understanding in this paper, wherever possible, the fragments will continue to be named glass shards.

The host rocks examined in core samples, should not be qualified as tuff (Schmid, 1981), since the amount of pyroclastic material (ash) present in any thin section studied did not usually exceed $25 \%$. In this paper they are named ash-carrying sediments. Vitroclastic tuffaceous sediments should perhaps be the name to be assigned to infrequent thin beds, lenses or local concentrations where the amount of shards surpasses $25 \%$. Partial results of this investigation were already presented at the 7 th Gondwana Symposium (Coutinho et al., 1988) and published by Coutinho et al. (1991). They are incorporated in the present paper, together with comparisons and interpretations of new petrographic data from outcrop occurrences, one of which, in Candiota, $\mathrm{RS}$, should be considered a tuff. The aim of this contribution is to document the lithological characteristics of the Permian ash-carrying sediments of the Paraná Basin, to correlate them with similar ones from other parts of Gondwana, to discuss their proximal or distal connection to conceivable volcanic centers and to trace a possible ash path from sources to deposition sites.

\section{DISTRIBUTION}

Table 1 and Figure 1 show the locality reported for 23 Permian volcanic or mixed deposits in the Paraná Basin.

Having in mind the sequence of Formations mentioned in Table 1, the Table 2 was elaborated in which a chronostratigraphic distribution of the Permian units of the Paraná Basin is correlated to the geological time scale (Gradstein et al., 2004) and to the biostratigraphic data from Daemon and Marques-Toigo (1991), modified by Hachiro (1996).

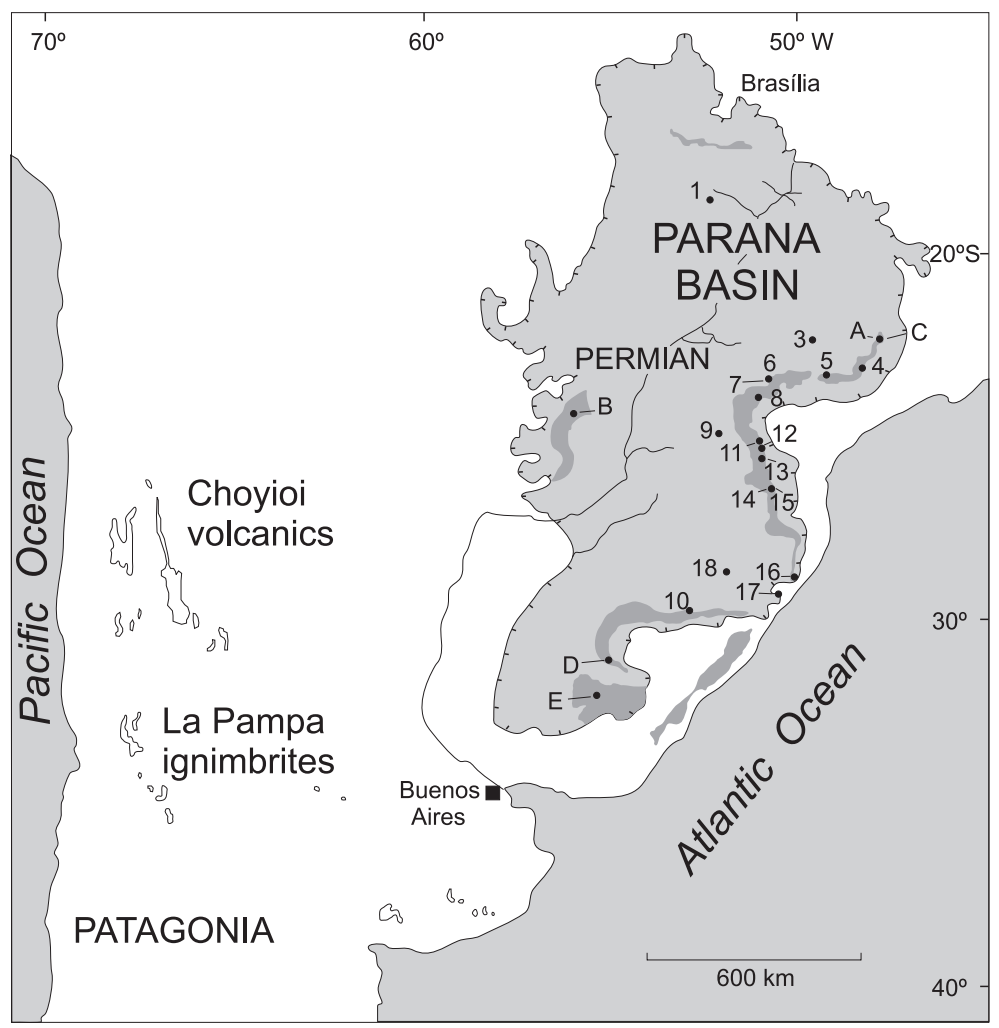

Figure 1. Location of 18 bore holes (numbers) and 5 outcrops (letters), which produced evidences of rhyolitic ash in Permian sediments of the Paraná Basin. The proposed sources are depicted by speckles and elongated blotches, representing volcanic centers in Northern Patagonia (La Pampa Province) and, farther north, in the Cordillera Frontal. 
Table 1. Permian volcanic or mixed deposits in the Paraná Basin.

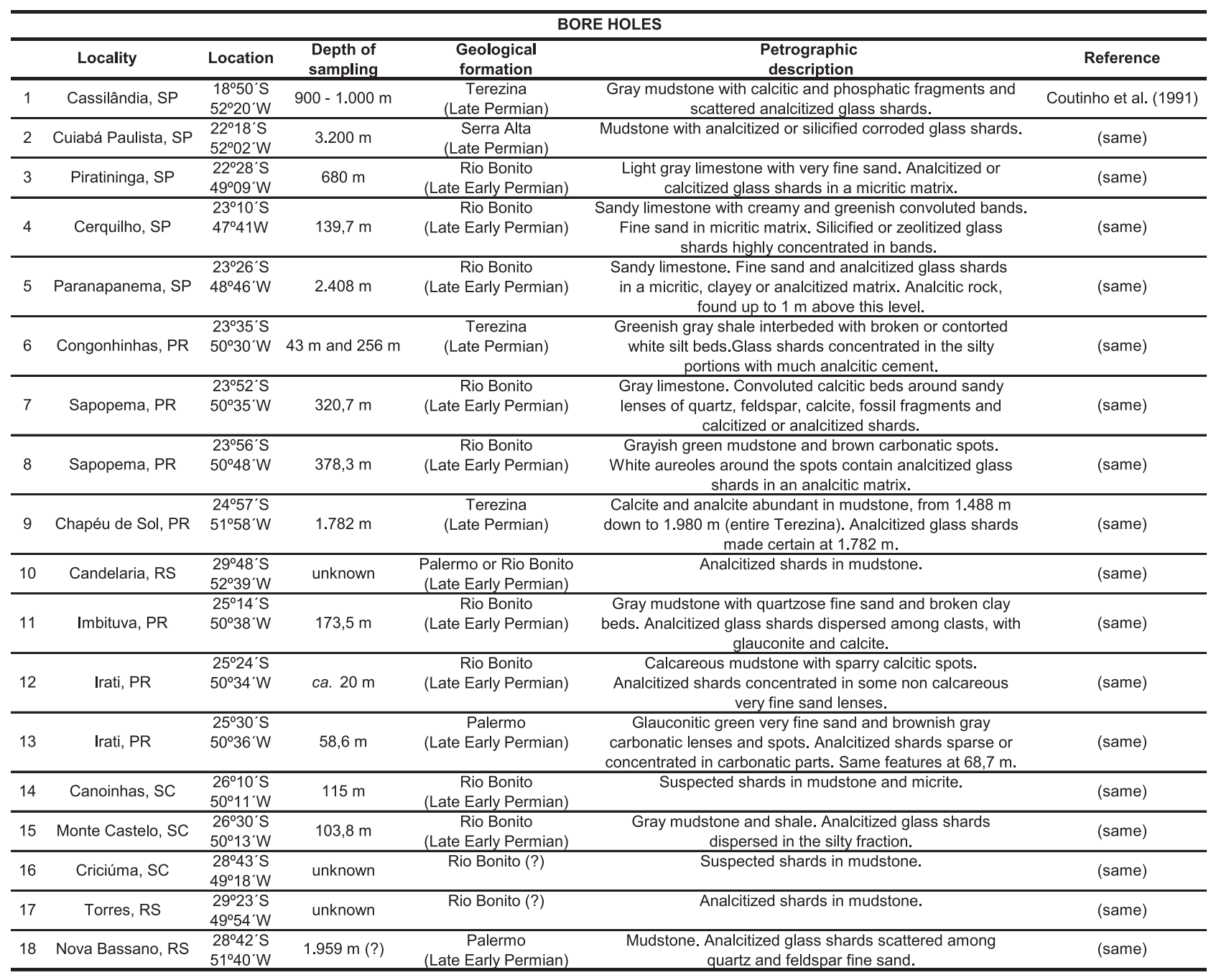

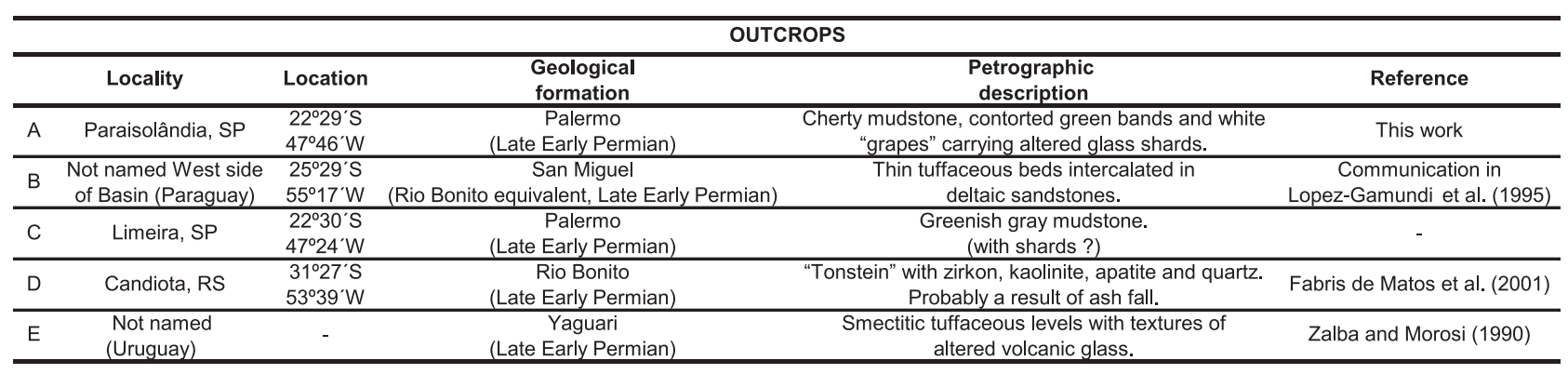


Table 2. Chronostratigraphic column for the Permian Period.

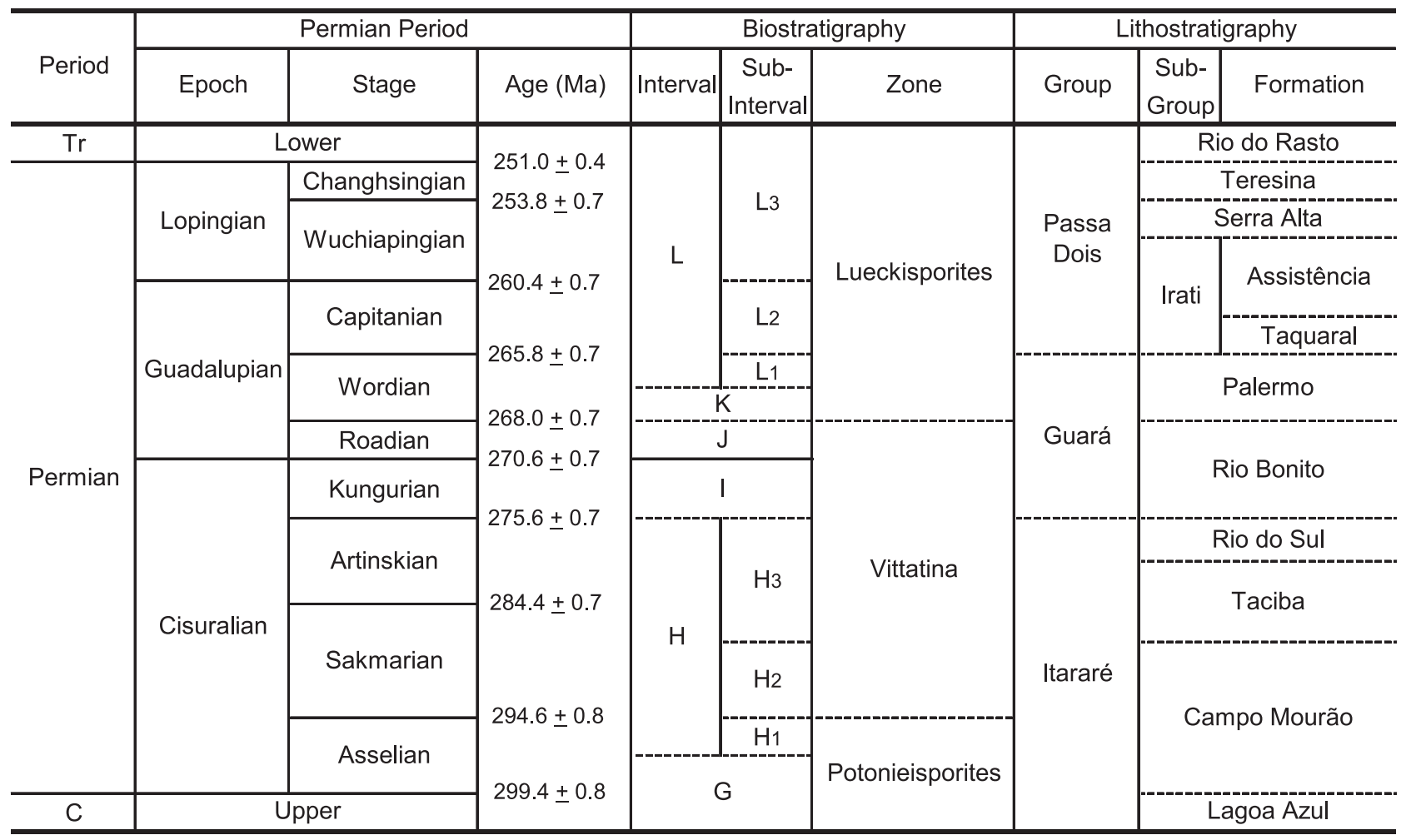

\section{THE GEOLOGICAL FORMATIONS}

The great majority of the occurrences recorded in Table 1 are ascribed to the Rio Bonito Formation, which is a stratigraphic pile erected during Late Early Permian times inside the Paraná Basin (Figure 1). The formation comprehends basal whitish, fine to medium-grained sandstones followed by grayish to greenish mudstones and clayey carbonates, which are commonly silicified at the surface. The upper member is composed of dark grey beds of thin, fine to very fine-grained sandstones, intercalated in carbon or coal-bearing shales.

This sedimentary sequence indicates initial deposition in a fluvio-deltaic environment followed by transgressive marine sedimentation. Later on, coastal sediments were accumulated over the marine sequence.

The Palermo Formation (five indications in Table 1), is marked by the transgressive deposition of grayish mudstones and fine sandstone in a broad shallow platform placed underneath the surf zone. The Late Permian, Serra Alta and Terezina Formations, registered in the sampled intervals of four bore holes, had its sediments deposited firstly in calm water, then in shallow agitated water of undertidal, intertidal or overtidal environments. The thickness of a section from the base of the Rio Bonito Formation to the top of the Terezina Formation in Southern Brazil is estimated to be something between $500 \mathrm{~m}$ to $1.000 \mathrm{~m}$. As evaluated by Gradstein et al. (in Table 2), their sediments were deposited during a period of 24.6 Ma.

\section{LOCATION OF GLASS SHARDS}

\section{In bore holes}

Bore hole shard-carrying samples were only found in intervals, which in this paper, are named "critical zone".

The shards were detected in eighteen holes drilled through the Permian of the Paraná Basin. Twenty-seven other holes were sampled and microscopically examined, but no ash remnants were found in the Permian units. In most of these cases, the sampling was made either above or below the critical zone. Another unfavorable condition for findings is the widely spaced sampling - more than $30 \mathrm{~m}$ which was the case even for the critical zone. It is also 
believed that certain rock types such as porous sandstones are not propitious hosts for glass shards. Seventeen thin sections left no doubt about the existence of true glass shards and in twenty-five others, signs of their actual or former presence in certain strata were given by suspicious fragment shapes and concentrations of secondary minerals (mainly analcite), known to be glass alteration products. In Monte Castelo, all five thin sections made from bore core samples in a $150 \mathrm{~m}$ interval between the base of Rio Bonito and the top of the Palermo Formation, exhibited true glass shards. In Congonhinhas, all 6 thin sections from samples in a $400 \mathrm{~m}$ interval between Rio Bonito and Terezina formations, presented either actual glass shards or their traces. The considerations above seem to prove that the volcanicity observed in the units considered as Permian lasted for prolonged periods inside or in the vicinities of Gondwanian Paraná Basin.

\section{In outcrops}

All five outcrops listed in Table 1 belong to Late Early Formations: Rio Bonito, Palermo or equivalents.

According to Fabris de Matos et al. (2001), the Candiota occurrence is a "tonstein" exposed in a coal-bearing strata of the Rio Bonito Formation. They favor the interpretation that kaolinitic "tonsteins" are distal pyroclastic fall deposits of instantaneous deposition. U-Pb dating of zircons from one type of "tonstein" set an age of $267.1+3.4$ Ma. Outcrops of Late Early Permian mudstone in Paraisolândia, SP, exhibit grape-like structures of controversial origin. The presence of shards in the Palermo occurrence near Limeira, SP, has not yet been confirmed. The outcrops in Paraguay and Uruguay, both from Late Early Permian, are said by Zalba and Morosi (1990) to carry tuffaceous beds, but their original publication is not available to the present authors, being therefore impossible to assert the real nature and origin of the volcanic glass found in these samples.

\section{MINERALOGICAL AND PETROGRAPHIC FEATURES}

\section{The glass shards}

Small amounts of glass shards appear in the "critical" zone of the eighteen holes listed in Table 1. The most common type seen in thin section (Figure $2 b$ ) is a flat or slightly curved plate that should be interpreted as a fragment of an exploded pumice whose vesicle glass walls were liberated to the atmosphere. The shards have an average length of $0,100(50) \mathrm{mm}$ and a width of $0,010(5) \mathrm{mm}$. In some samples the shards are broken or have serrated edges produced by incipient dissolution. The mineral substance in the shards is similar to that of modern obsidian, which is replaced in most cases by analcite, and in a few examples, by silica, montmorillonite, carbonate or zeolites. Analcite has been positively identified by the 3.43, 5.61, 2.93, $1.74 \mathrm{~d}$-spacings observed in X-ray powder diagrams obtained in samples rich in isotropic low refringent material. Products of pumice fragmentation are the doubly concave plates (X shaped in cross section, Figure 2c) representing the wall junction of two bubbles or the triple concave fragments ( $\mathrm{Y}$ shaped in cross sections), which are the remnants of three adjoining bubbles.

The shapes of the described ash fragments clearly reveal their origin as disintegrated pumice of silicic magma (Fisher and Schmincke, 1984). When ejected from volcanic craters, ashes usually consist of a mixture of crystals and glass fragments. Since crystals are denser than glass, crystals and crystal-carrying glass fragments tend to sediment faster than the crystal-free glass shards. Thus, crystals are more abundant in ash deposits close to the vent and become less and less frequent at increasing distance (Macdonald, 1972). Acid (rhyolitic) magmas are ejected in violent and explosive eruptions. Their ashes travel great distances, sometimes many thousands of kilometers before falling.

The shards here examined did not exceed $0,150 \mathrm{~mm}$ in length and presented no traces of embedded phenocrysts. Furthermore, no volcanic quartz or feldspar were recognized among the clastic components of sediments. It is worth mentioning, however, that in "tonsteins" from the coal mines of Candiota, RS (outcrop D, Table 1), Fabris de Matos et al. (2001), reported the presence of euhedral zircon, apatite, and paramorphs of beta-quartz, scattered in the kaolinitic mass. Such a mode of occurrence strongly suggests a parental rhyolitic magma. The above mentioned authors, following Bohor and Triplehorn (1993), believe that such "tonsteins" are altered tephra brought from distal sources. In our opinion, however, "tonsteins" could be better interpreted as bodily deposits of very dense ash clouds or even fluidized pyroclastic debris flowed from not too distant volcanic vents.

Based on the size of shards, the grain size of juvenile zircons $(0,080$ to $0,220 \mathrm{~mm})$ and geochemical and tectonomagmatic considerations, Bangert et al. (1993) propose two different sources for the Carboniferous-Permian tuff horizons in Namibia and South Africa. The majority of the silicic ash would come from a distant collar of volcanic vents fringing Southern Gondwana (Patagonia?). On the other hand, the larger grain size of pyroclasts together with the occurrence of pyroclastic flows, imply a contribution from closer as yet unidentified source.

It is reasonable to conclude that the shards found in the Paraná Basin Permian sediments derived from ashes formed from silicic and highly vesiculated magma and which were 
carried from very distant sources before settling. Izett (1981) presented evidence to show that pumice shards tend to develop from relatively viscous rhyolitic magma at temperatures below $850^{\circ} \mathrm{C}$ whereas bubble wall and bubble junction shards, the only types described in this paper tend to be developed from more fluid rhyolitic magmas at temperatures above $850^{\circ} \mathrm{C}$.

\section{SEDIMENT COMPOSITION}

The Permian sedimentary rocks of the Paraná Basin were studied in thin sections taken from forty-five bore hole core samples. They can be classified as shaly or calcareous mudstone or as micritic or sparritic limestone. The decimeterlong cores exhibit either a somewhat vague planar bedding (Figure 3a) or a distinct structure of spots, contorted beds and ovoids. Such ovoids are found in core samples from bore holes 4, 6 and 7 and in outcrop A (Figure 3, b and c). Their appearance recalls the so-called "grapes" or "graupen", described by Bohor and Triplehorn (1993) as ovoidal or ellipsoidal kaolinite aggregates found in "tonstein" and believed to be altered volcanic ash. "Grapes" have been interpreted as modified pumice lumps, but no original textures have been detected. Nevertheless in the Paraná Basin, the "grape"-like bodies keep internally undisturbed features (Figure 2a) and show no traces of glass shards larger than $0.1 \mathrm{~mm}$.

Mudstones usually contain $65 \%$ to $75 \%$ of "clay" matrix and a variable proportion ( $20 \%$ to $40 \%$ ) of well- sorted silt, which ranges from $0,020 \mathrm{~mm}$ to $0,060 \mathrm{~mm}$ in grain size. Besides abundant ( $70 \%$ to $80 \%$ ) quartz, other clearly terrigenous epiclastic silt components are, in decreasing abundance order: K-feldspar, plagioclase, clastic calcite, magnetite, mica-quartz clasts, mica, glauconite, opaque and heavy minerals. Mica is prominent only in shaly beds.

Figure 2. Photomicrographs. Uncrossed polarizers. a) Internal texture of a grape. Sedimentary bedding is not disturbed by the formation of curved layers. Outcrop A. Photo width: $0.4 \mathrm{~mm}$. b) Usual appearance of glass shards in mudstone beds. Flat, curved and y-shaped analcitized shards are scattered among clastic clay and silt components. Bore hole 8. Photo width: $0.4 \mathrm{~mm}$. c) Contact between micrite (lower right) and mudstone (upper left). Analcitized glass shards are common in the mudstone. In the micritic area they are not common, but one analcitized double concave shard is well preserved. Bore hole 5. Photo width: $0.4 \mathrm{~mm}$. d) Diagenetic changes in sediment: calcite and idiomorphic analcite fill one open space in the micritic host rock (lower left and upper right) where tiny albite crystal laths are seen dispersed.
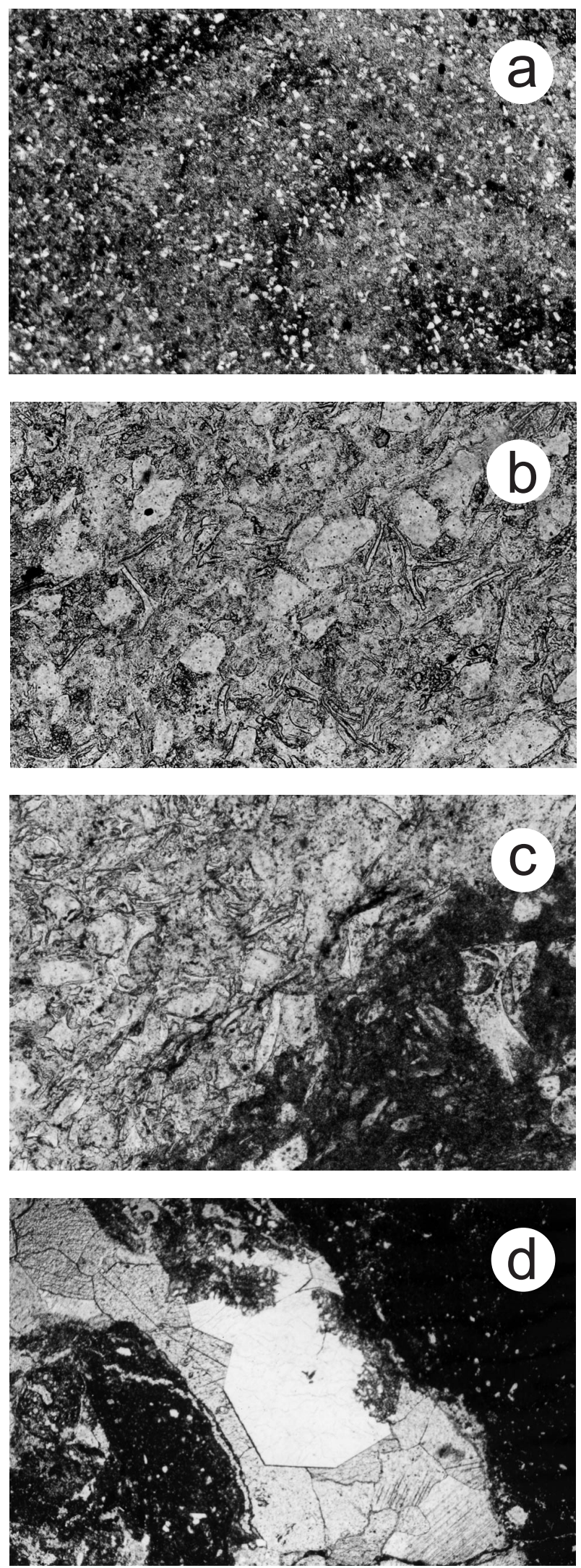
Garnet and minor tourmaline, zircon and rutile were identified in the heavy-mineral concentrate from the silt fraction. Except for authigenic glauconite, all other terrigenous silt grains are anhedral, angular or subangular. Such grains must result from disintegration of rocks in granitic and metamorphic terrains, a process followed by transportation, sorting and deposition of debris into a shallow marine site. This environment is indicated by the common presence of authigenic calcite and especially glauconite. In all non-calcareous samples, clayey material largely predominate in argillite beds or make up the matrix for mica, quartz and feldspar grains in silty clay beds. The matrix is an aggregate of particles that measure less than $0,010 \mathrm{~mm}$ in diameter, a size that turns the grains almost isotropic under the microscope. As studied in core samples and in outcrop $\mathrm{A}$, the matrix comprises $65 \%$ to $85 \%$ of the rock volume. It is sometimes mixed with chlorite, dusty calcite or some other authigenous minerals.

Employing the immersion method and by comparison with Canada balsam in old thin sections, it was possible to attain an average refractive index for the aggregate matrix on crushed material from bore holes 5, 8, 14 and outcrop A. The data obtained, $\mathrm{nm}=1.535(5)$, suggest that cherty silica and mixed clay minerals are the main components of the aggregates. In fact, all the four X-ray diagrams obtained for crushed mudstones showed the peaks of montmorillonite and illite. Quartz and feldspar were always present and kaolim, possibly a product of feldspar weathering, appeared in two preparations. Halloysite did not show up and traces of analcite were identified in two patterns.

Other diffratograms were then obtained from four fractions of crushed, elutriated and decanted material that formed white and green bands in fresh samples of outcrop A mudstone. As expected, quartz, feldspar, analcite, calcite and clay mineral peaks appeared in all preparations, montmorillonite (14.310) and illite (10.09) peaks being particularly intense in the finest fraction. Treatment with ethylene glycol also showed the presence of montmorillonite by the shift of its $c$ dimension to $17.0 \mathrm{~A}$.

Figure 3. Sedimentary structures of mudstones. a) "Grape" like is seen on a polished plate taken from outcrop A. b) "Grape" unit exhibiting light-colored outgrowths as seen on the same plate. Photo width $3.2 \mathrm{~cm}$. c) Plane-parallel bedding formed by intercalated shaly and clayey laminae. About $20 \%$ of quartz-feldspathic silt is dispersed trough both units. Bore hole 15. Photomicrograph width: $5 \mathrm{~mm}$.
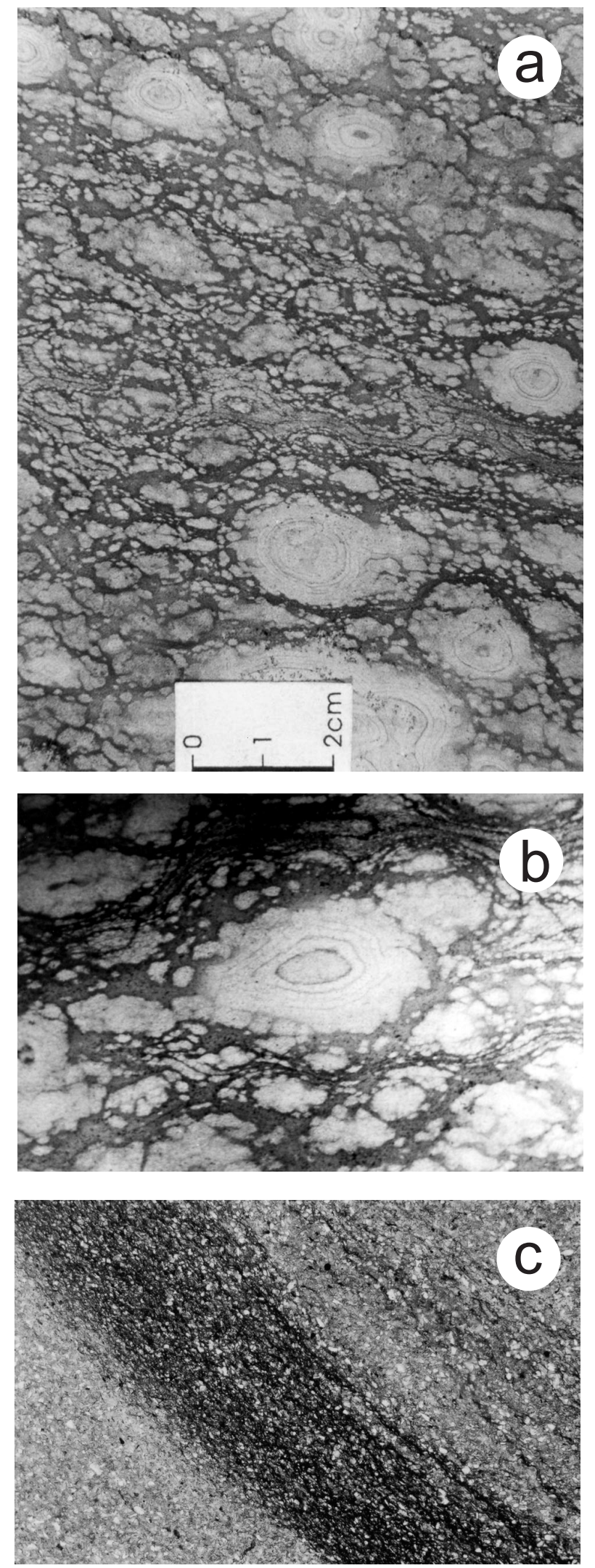


\section{DIAGENETIC GENERATION OF MINERALS IN THE SEDIMENT}

Probably as a result of burial pressure, temperature and intrastratal chemical activity, most structures and minerals in the Permian Paraná Basin sediments were diagenetically modified.

The commonest replacement mineral in the glass shards, observed under the microscope, is analcite. The usually replacing mineral in glass shards is analcite, which together with calcite, is found also filling cavities (Figure 2d), as a product of diagenetic mobilization and precipitation. It has been generally acknowledged that for the generation of analcite and zeolite, a basaltic parental magma should be assumed.

Muller (1967), however, draws attention to the occurrence of huge deposits of analcite in the Central Congo Basin generated in alkaline lakes rich in silica, alumina and soda. As observed in other parts of Central-East Africa, an alkalic volcanism might be involved in the formation of sodarich lakes in the Permian Paraná Basin. Muller notes that analcite is one of the main products of low temperature reaction between glass shard-carrying sediments and the lake waters of restricted basins.

Studying thick volcanic piles in Japan, Iijima (1978), distinguishes a downward succession of four zones, each dominated by mineral assemblages of the reaction series: silica glass - alkali zeolite - albite. In zone I, part of silicic glass alters to montmorillonite and opal. In zone II, the remaining silica glass reacts with interstitial water and alkalic zeolites plus montmorillonite. In zone III, the alkalic zeolites are transformed into analcite, which in the deepest zone IV, changes to albite. Relics of precursor montmorillonite, opal (or chalcedony) and zeolites persist in the succeeding zone. Analcite forms in zone III at depth of $1.700-3.500 \mathrm{~m}$ at $89^{\circ}-91^{\circ} \mathrm{C}$.

Authigenic albite was detected in a few thin sections of the Paraná Basin rocks, but other neoformed minerals, described in the Japanese pile, are abundant in the shard-carrying sediments. These minerals include montmorillonite, alkalic zeolites, opal (or chert) and analcite, which may have been formed by the same or similar process as the Japanese. Excess silica (opal), a by-product generated in every step of analcite formation, is now represented by quartz and chert. It is here suggested that the diagenetic depth-temperature active in the Paraná Basin sediments were close to those required for the formation of analcite in the Japanese zone III, i.e., depth of $1.700-3.500 \mathrm{~m}$ at $89^{\circ}-91^{\circ} \mathrm{C}$. In places where albite was formed, the PT requirements may have been a bit more severe.

\section{PROVENANCE}

Several authors (Coutinho et al., 1988; Amaral, 1987) had already looked for rhyolitic volcanic centers of Early Permian age around the Gondwanian Basins in the Southern hemisphere. Amaral (1987) also pointed out that the end of the Permian period in South America witnessed intense acid (to intermediate) volcanism stretching from the Argentinian Sierras Pampeanas northward along the Chile-Argentine frontier. He also noticed that volcanic material had been identified in the Irati Formation and in lower Tatui Formation in which geochronological determinations indicated synchronism of eruption and deposition events. Apropos it is worth specifying here that $\mathrm{U}-\mathrm{Pb}$ radiometric dating on zircon from bentonite horizons of the Irati Subgroup gave $263+\mathrm{Ma}$ (Hachiro and Yamamoto, in preparation).

Coutinho et al. (1982) had previously directed attention to the occurrence of rhyolitic ash sources along the Argentinian Cordillera Frontal, Permian Choyioi Volcanics (Ramos et al., 1986), and "Formación Variscica de Choyioi" (Caminos et al., 1979). Farther southeast, another possible source is envisaged in the volcanic ignimbritic plateau of western La Pampa Province (Lambias and Leveratto, 1975). Both source sequences were plotted in Figures 1 and 4.

Other possible places of parental volcanism could be sought in the Permian terrains of Tierra del Fuego and farther south, in the Graham Land of the Antarctic Peninsula where Smellie (1988) detected Early Jurassic silicic volcanism. As far as the present authors are aware, there are no records of powerful Permian rhyolitic eruptions outside the above mentioned South American regions that could justify such vast distribution of tuffaceous sediments in Gondwana.

In South Africa, Elliot and Watts (1974) described ash fall tuff horizons in many bore holes and outcrops from the Permian Ecca and Beaufort Groups. Martini (1974), McLachland and Jonker (1990) and the majority of authors interested in the matter, agree to the view that the sources for the African tuffaceous units should be located in Patagonia and/or West Antarctica.

In Antarctica, Vavra et al. (1980) reported Triassic volcanic detritus in the Transantarctic Mountains, and Barret (1991) describes ash beds in the Early Permian of Polarstar and Mt. Glossopterix Formation. Barret et al. (1972) concluded that the volcanic material observed in the Beacon Supergroup of East Antarctica came from the Permian volcanic centers in West Antarctica, which is an extension of Patagonia.

In Eastern Australia, Bangert et al. (2001) described a thin bed of re-sedimented tuffaceous mudstone in Upper Permian terrains. Few samples were collected and studied. The rock is interpreted as a product of distal pyroclastic fallout related to a large-scale eruptive episode. Michelson et al. (2001) also suggested that a Permian tephra bed found in coal measures of Northern Bowen Basin "implies a distant source".

In conclusion, excluding examples of proximal tuffs, and 


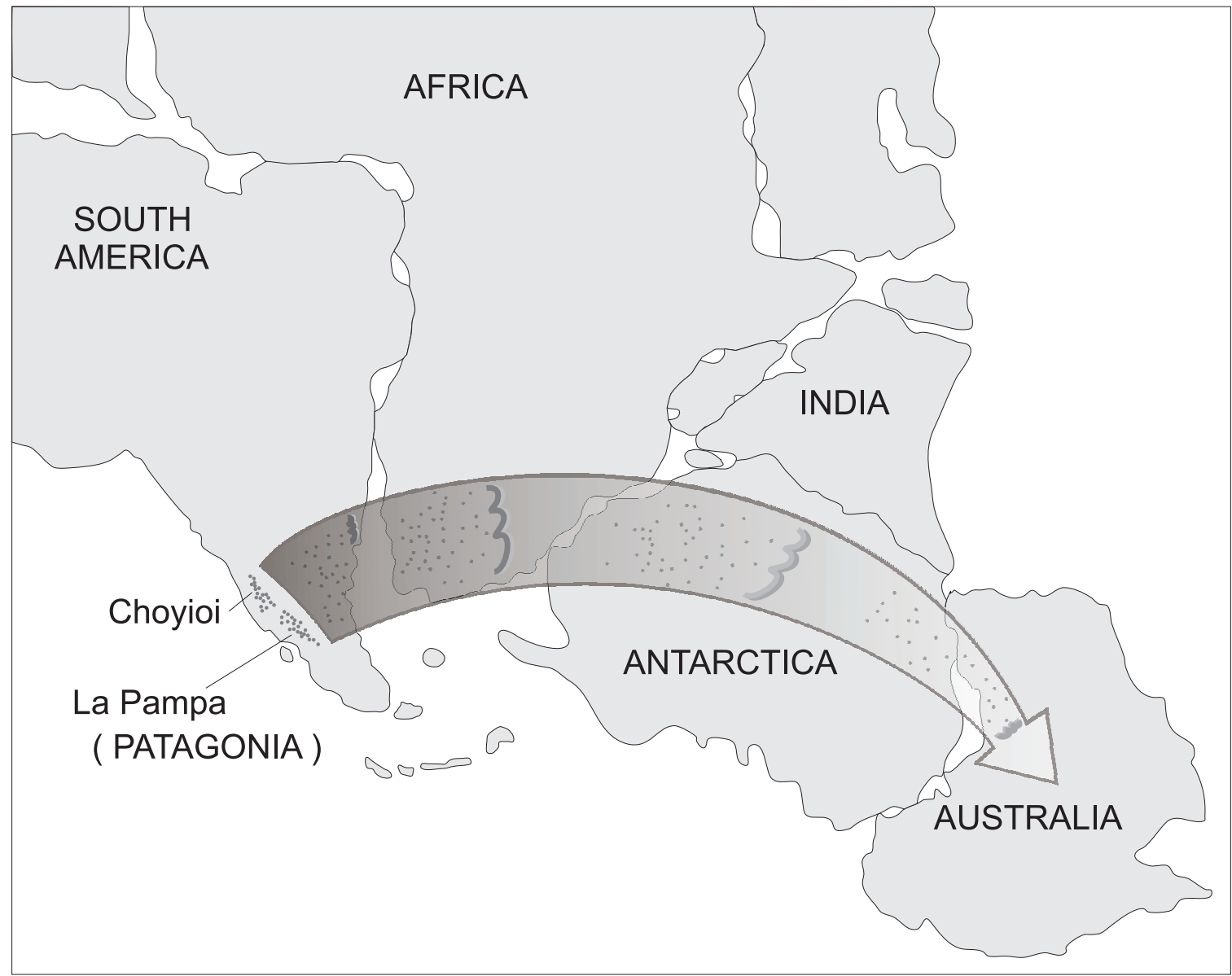

Figure 4. Late Paleozoic reconstruction of Gondwana showing the path of volcanic clouds in Permian times. Arrow: feature drawing with heavy-to-light shading, in the author's interpretation, depicts the eastward track of the deposits with decreasing discharge of ashes as clouds traveled from Patagonia to Australia. Desenho elaborado por Yara Coutinho Pasetchny.

taking into account the decreasing number of ash fall occurrences reported for the route from Patagonia towards Australia, it is suggested, as shown in Figure 4, that in Permian times Patagonia-derived clouds traveled NE discharging progressively less ash along its way.

In conclusion, excluding cases of proximal tuffs and reasoning out of the decreasing number of ash fall occurrences reported for the route Patagonia towards Australia, it seems fair to suggest that in Permian times, Patagonia-derived clouds traveled NE discharging progressively less ash along the way. Such outlook is depicted in Figure 4.

\section{ACKNOWLEDGMENTS}

The authors acknowledge the support from FAPESP (contract n $\mathrm{n}^{\circ}$ 01/08059-7) for the project "Estudo petrográfico e faciológico das unidades permotriássicas da Bacia do Paraná no Estado de São Paulo", to colleagues from IPT S.A. for their early contribution in the presentation of data and to Professors Ian McReath and Miguel Ângelo Stipp Basei for suggestions and critical review of the manuscript.

\section{REFERENCES}

AMARAL, G. Paleogeografia da América do Sul no Fanerozóico e suas relações com a evolução da plataforma sul-americana. In: SIMPÓSIO REGIONAL DE GEOLOGIA, 6., 1987, Rio Claro. Atas... Rio Claro: SBG-São Paulo, 1987. v. 1, p. 243-261.

BANGERT, B.; STOLLHOFEN, H.; LORENZ, V.; ARMSTRONG, R. The geochronology and significance of ash fall tuffs in the glaciogenic Carboniferous-Permian 
Dwyka Group of Namibia and South Africa. Journal of African Earth Sciences, v. 29, n. 1, p. 33-50, 1999.

BARRET, P. S. The Devonian to Jurassic Beacon Supergroup of the Transantarctic Mountains and correlatives in other parts of Antarctica. In: TINGEY, R.J. (Ed.). The Geology of Antarctica. Oxford: Oxford University Press; New York: Clarendon Press, 1991. p. 120-153. (Oxford Monographs on Geology and Geophysics, 17).

BARRET, P. J.; GRINDLEY, G. V.; WEBB, P. N. The Beacon Supergroup of East Africa. In: Adie, R. M. (Ed.). Antarctic geology and geophysics. Oslo: Universitetsforlaget, 1972. p. 319-332.

BOHOR, B. F.; TRIPLEHORN, D. M. Tonsteins: altered volcanic ash layers in coal-bearing sequences. Washington: The Society, 1993. (Geological Society of America. Special Paper, 285).

CAMINOS, R. Cordillera Frontal. In: SIMPOSIO DE GEOLOGÍA REGIONALARGENTINA, 2., 1979, Córdoba. Córdoba: Academia Nacional de Ciencias, 1979. v. 1, p. 397-453.

COUTINHO, J. M. V. et al. "Ash fall " permiano na Bacia do Paraná. In: CONGRESO LATINOAMERICANO DE GEOLOGIA, 5., 1982, Buenos Aires. Resúmenes... Buenos Aires: s.n., 1982.p. 127.

COUTINHO, J. M. V. et al. Ash-fall derived vitroclastic tuffaceous sediments in the Permian of the Paraná Basin and its provenance. In: ULBRICH, H. H. G. J.; ROCHACAMPOS, A. C. (Ed.). Gondwana seven proceedings: papers presented at the Seventh International Gondwana Symposium, Sao Paulo, 18-22 July, 1988. São Paulo: Instituto de Geociências, 1991.p. 147-160.

CURTIS, C. D. Clay mineral precipitation and transformation during burial diagenesis. Philosophical Transactions of the Royal Society of London, v. 315, p. 91-105, 1985.

DAEMON, R. F.; QUADROS, L. P. Bioestratigrafia do Neopaleozóico da Bacia do Paraná. In: CONGRESSO BRASILEIRO DE GEOLOGIA, 34., 1970, Brasília. Anais... Brasília: s.n., 1970. p. 359-412.

DAEMON, R. F.; MARQUES-TOIGO, M. An integrated biostratigraphic column for the Paraná Basin. In: INTERNATIONAL CONGRESS OF CARBONIFEROUS-PERMIAN STRATIGRAPHY AND GEOLOGY, 12., Buenos Aires, 1991.
Abstracts... Buenos Aires: s.n., 1991.p. 25-27.

DE GENARO, M.; CAPPELLETTI, P.; LANGELLA, A.; PERROTA, C. S. Genesis of zeolites in the Neapolitan yellow tuff: geological, volcanological and mineralogical evidence. Contributions to Mineralogy and Petrology, v. 139, p. 17-35, 2000 .

ELLIOT, D. H.; WATTS, D. R. The nature of volcanoclastic material in some Karroo and Beacon rocks. Transactions of the Geological Society of South Africa, v. 77, p. 109-111, 1974.

FABRIS DE MATOS, S. L.; YAMAMOTO, J. K.; RICCOMINI, C.; HACHIRO, J.; TASSINARI, C. C. G. Absolute dating of Permian ash-fall in the Rio Bonito Formation, Paraná Basin, Brazil. Gondwana Research, v. 4, n. 3, p. 421-426, 2001.

FABRIS DE MATOS, S. L.; YAMAMOTO, J. K.; HACHIRO, J.; COIMBRA, A. M. Tonsteins da Formação Rio Bonito no depósito de carvão Candiota, R.S. Revista Brasileira de Geociências, v. 30, p. 679-684, 2001.

FISCHER, R. U.; SCHMINCKE, H. U Pyroclastic rocks. Berlin: Springer Verlag, 1984.

GLADSTEIN, F. M.; OGG, J. G; SMITH,A. G., BLEEKER, W.; LOURENS, L. J. A new Geologic Time Scale, with special reference to Precambrian and Neogene. Episodes, v. 27, n. 2, p. 83-100, 2004.

GULBRANDSEN, R. A.; CRESSMAN, E. R. Analcime and albite in altered Jurassic tuff in Idaho and Wyoming. Journal of Geology, v. 68, n. 4, p. 458-464, 1960.

HACHIRO, J. O Subgrupo Irati (Neopermiano) da Bacia do Paraná. 196 p. 1996. Teses (Doutorado) - Instituto de Geociências, Universidade de São Paulo, São Paulo.

HACHIRO, J.; YAMAMOTO, J. K. Absolute dating of Irati, Subgroup Paraná Basin, Brazil. Não publicado.

HAY, R. L.; GULDMAN, S. G. Diagenetic alteration of silicic ash in Searles Lake, California. Clay and Clay Minerals, v. 35, n. 6, p. 449-457, 1987.

IIJIMA, A. Geological occurrences of zeolites in marine environments. In: INTERNATIONAL CONFERENCE ONTHE OCCURRENCE PROPERTIES AND UTILIZATION OF NATURAL ZEOLITES, 1976, Tucson, Arizona. Oxford: Pergamon, 1978. p. 175-198. 
IZETT, G. A. Volcanic ash beds, recorders of Upper Cenozoic silicic pyroclastic volcanism in Western US. Journal of Geophysical Research, v. 86, p. 10200-10222, 1981.

LLAMBIAS, E. J.; LEVERATTO, M. A. El plateau riolítico de la Provincia de La Pampa, Republica Argentina. In: CONGRESO IBERO-AMERICANO DE GEOLOGÍA ECONÓMICA, 2., 1975, Buenos Aires. Buenos Aires: s.n., 1975. p. 99-115.

LOPES-GAMUNDI, O. R. Permian volcanic activity along the Proto-Pacific plate margin reflected in the basins of Southern South America. In: GONDWANA SYMPOSIUM, 9., 1994, Hyderabad, India. Proceedings... New Dheli: Geological Survey of India, 1994. v. 2, p. 833-838.

LOPES-GAMUNDI, O. R.; CONAGHAN, P. J.; ROSSELLO, E. A.; COBBOLD, P. R. The Tunas Formation (Permian) in the Sierras Australes foldbelt, East Central Argentina; evidence of syntectonic sedimentation in a foreland basin. Journal of South American Earth Sciences, v. 8, p. 129-142, 1995.

MICHAELSEN, P.; HENDERSON, R. A.; CROSDALE, P. J.; FANNING, C. M. Age and significance of the Platypus Tuff Bed, a regional reference horizon in Upper Permian Moranbah coal measures, North Bowen Basin. Australian Journal of Earth Sciences, v. 48, p. 183-192, 2001.

MARTINI, J. E. J. On the presence of ash beds in volcanic fragments in the graywacke of the Karoo System in Southern Cape Pravince (South Africa). Transactions of the Geological Society of South Africa, v. 77, p. 113-116, 1974.

MULLER, G. Diagenesis in argillaceous sediments. In: LARSEN, G.; CHILLINGER, G.V. (Ed.). Diagenesis in sediments. Amsterdam: London: Elsevier, 1967. p. 127-179. (Developments in Sedimentology, 8).

MCLACHLAN, I. R.; JONKER, J. P. Tuff beds in the northwestern part of the Karoo Basin. South African Journal of Geology, v. 93, p. 329-338, 1990.

RAMOS, D. A.; JORDAN, T. E.; ALLMENDIGHER, R. W.; MPODOZIS, C.; KAY, S. M.; CORTÉS, J. M.; PALMA, M. Paleozoic terrains of the Central Argentine-Chilean Andes. Tectonics, v. 5, p. 855-880, 1986.

SCHMID, R. Descriptive nomenclature and classification of pyroclastic deposits and fragments: recommendations of the IUGS Subcommission on the systematics of igneous rocks. Geology, v. 9, p. 41-43, 1988.

BRASIL. Ministério das Minas e Energia. Departamento Nacional da Produção Mineral. Geologia do Brasil: texto explicativo do mapa geológico do Brasil e da área oceânica adjacente incluindo depósitos minerais, escala 1:2500000. Brasília: DNPM, 1984.

SMELLIE, J. L. Early Jurassic volcanism in East-Central Graham Land, Antarctic Peninsula, and its relationship to the break-up of Gondwana. In: ULBRICH, H. H. G. J.; ROCHA CAMPOS, A. C. (Ed.). Gondwana seven proceedings: papers presented at the Seventh International Gondwana Symposium, Sao Paulo, 18-22 July, 1988. São Paulo: Instituto de Geociências, 1991.p. 565-588.

VAVRA, C. R.; STANLEY, K. O.; COLLISON, J. W. Provenance and alteration of Triassic Fremouw Formation, Central Transantarctic Mountains. In: CRESSWELL, M. M.; VELLA, P. (Ed.). Gondwana five: selected papers and abstracts of papers presented at the fifth International Gondwana Symposium, Wellington, 11-16 February, 1980. Rotterdam: Balkema, 1981.p. 149-153.

ZALBA, P. E.; MOROSI, M. E. Mineralogía de la bentonita permica de la Formación Yaguari, Uruguay. In: ANNUAL MEETINGOF THE WORKING GROUP: LATEPALEOZOIC OF SOUTH AMERICA, Buenos Aires, 1990. Abstracts... p. 147-150. Proyecto 211 IGCP, IUGS-UNESCO. 